УДК 94(571.1):911

ББК 63.3(253.3)

\title{
Природно-географическое районирование Алтайского округа в трудах ученых и путешественников рубежа XIX-XX вв.
}

\author{
К.А. Пожарская
}

Алтайский государственный университет (Барнаул, Россия)

\section{Natural and Geographical Zoning of the Altai District in the Works of Scientists and Travelers at the Turn of $19^{\text {th }}-20^{\text {th }}$ Centuries}

\author{
K.A. Pozharskaya
}

Altai State University (Barnaul, Russia)

\begin{abstract}
Основываясь на публикациях рубежа XIX-XX вв. ученых, путешественников и сотрудников ведомств различного уровня, автор реконструирует природногеографический образ Алтайского округа. Делается вывод об отходе в исследуемый период от представления об Алтае как регионе, чрезвычайно благоприятном для земледельческой культуры и монолитном по своим климатическим условиям. Отмечается, что большинство исследователей природно-географической конъюнктуры Алтая квалифицировали ее как весьма гетерогенную и разнообразную по своим естественным доминантам. Подчеркивается, что эксперты рубежа веков не только осуществили описание базовых параметров естественной среды (рельеф, термический режим, гидрографические и почвенные условия), но и выделили уникальные, сравнительно с другими территориями, природно-климатические явления (температурная амплитуда, распределение осадков, специфика орошения поверхности и др.). Делается заключение, что предложенное специалистами районирование заложило основы для собственно научного изучения Алтая, поставило на повестку дня вопросы об организации рационального хозяйствования в регионе и риске для развития зернового хозяйства непродуманной колонизации.

Ключевые слова: Алтайский округ, естественно-географический образ региона, научная экспертиза, колонизация, природные условия, климат.
\end{abstract}

DOI 10.14258/izvasu(2019)2-06

Проблема влияния природно-географического фактора на ход и особенности российской истории с XIX столетия формировала предметное поле отечественной науки и активно дискутировалась
Based on the publications of scientists, travelers and department officers at the turn of $19^{\text {th }}$ and $20^{\text {th }}$ centuries, the natural-geographical image of the Altai District is being reconstructed. During the period under study, it was decided to abandon the idea of the region as extremely favorable for the agricultural crop and monolithic in its climatic conditions. It is noted that the majority of researchers in the natural geographical conjuncture of Altai qualified it as very heterogeneous and diverse in their natural dominants. At the turn of the century it is emphasized that experts not only carried out a description of the basic parameters of the natural environment (relief, thermal regime, hydrographic and soil conditions), but also identified unique climatic phenomena (temperature amplitude, distribution of precipitation, specificity of surface irrigation and etc.). In conclusion, it is noted that the regionalization proposed by the specialists laid the foundation for the actual scientific study of Altai and put on the agenda questions of economizing and the risk for the development of grain farming unreasoned colonization.

Key words: the Altai district, natural-geographical image, scientific expertise, colonization, natural conditions, climate. в общественно-политических кругах. Особый виток интереса к специфике естественного «развития» Российской империи стимулировали массовые крестьянские переселения на окраины страны во второй 
половине XIX - начале XX в. Потребность в прогнозировании экономических и демографических последствий разнонаправленных и масштабных миграций обусловила необходимость осуществления экспертизы колонизируемых территорий с точки зрения их пригодности для успешной жизнедеятельности и эффективного крестьянского хозяйствования. В этой связи специалистами различного профиля и ведомственного подчинения подверглись изучению разнообразные составляющие природной среды осваиваемых территорий (термические условия, гидрография, орография, состав почвы и т.д.), в том числе и Алтайского округа, являвшегося одним из ведущих районов заселения.

В настоящее время активное освоение исторической наукой дефиниции «адаптация» потребовало пристального внимания к природно-географическому контексту обустройства мигрантов из европейской части России в колонизуемых местностях. Это выразилось в появлении целого ряда публикаций, отражающих причины и содержание трансформации элементов материальной культуры русских сибиряков в естественно-географической обстановке Зауралья [1, с. 20]. Однако относительно обширная историография рубежа XIX-XX вв. до сих пор не являлись объектом специального анализа историков, слабо привлекалась в качестве источниковой базы исследований [2-5] и представляет значительный эвристический потенциал для реконструкции историко-географического образа Алтая.

Алтайский округ ведомства Кабинета Его Императорского Величества (далее - Кабинет) традиционно имел славу земледельческого эльдорадо, чему способствовали как широко тиражируемые обывательские представления крестьян [6], так и сведения о богатстве почв Алтая, содержащихся в исследованиях И.Г. Гмелина, П. Палласа, Ф. Гумбольдта, К. Ледебура, Й. Гагемейстера и др. [7, с. 63]. Тем не менее, как уже отмечалось, на рубеже XIX-XX вв. начинается качественно новый «углубленный» этап изучения природно-географической конъюнктуры алтайского региона, выразившийся в появлении значительного количества публикаций, хотя и существенно разнящихся по своему эвристическому потенциалу, методике исследований, характеру и стилю изложения материала. В целом, значительная часть специалистов квалифицировали округ по естественным (и соответственно сельскохозяйственным) условиям как гетерогенный, формируя представление о территории как отнюдь не монолитной по своему земледельческому потенциалу. На основе базовых компонентов природы округа (рельеф, климат, почва и гидрография) ученые подразделили его на три зоны: равнинную (западные части Барнаульского и Змеиногорского уездов, юго-западная половина северной части Бийского уезда), холмистую (восточная часть Барнаульского, западная часть Бийского уездов, средняя часть Змеиногорского уезда, северная половина Кузнецкого уезда, юг Томского уезда) и горную (южная половина Бийского и восточная часть Змеиногорского уездов, южная часть Кузнецкого уезда) $[8$, с. 3 ; 9 , с. $29 ; 10$, с. I; 11 , с. $39-42 ; 12$, с. $1-15$; 13 , с. $4 ; 14$, с. $7 ; 15$, с. $2-6 ; 16$, с. 53$]$.

Относительно климата Алтайского округа в целом специалисты оценили его как более суровый и потому менее комфортный для жизнедеятельности крестьян. Это связывали с низким значением в $0,4^{\circ} \mathrm{C}$ среднегодовой температуры, в то время как для европейской части России этот показатель исчислялся в $5,5^{\circ} \mathrm{C}[17$, с. $3-4 ; 18$, с. 7]. Устанавливалось, что средняя годовая температура на Алтае в отдельные годы подвергалась значительным колебаниям, характерным и для каждого месяца в отдельности [19, с. 9]. Столь низкие среднегодовые температуры ученые объясняли особенностями географического положения региона на Евразийском материке. Продвижение с севера холодных воздушных потоков на территорию округа, расположенного на Обской низменности, задерживалось на юге горами, что в свою очередь и обусловливало преобладание низких годовых температур по всей территории [19, с. 5; 20, с. 24; 21, с. 30]. При этом дифференцированный подход позволил определить среднегодовую температуру равниной части в $+0,78^{\circ} \mathrm{C}$; холмистой $-+0,35^{\circ} \mathrm{C}$; горной $--1,5^{\circ} \mathrm{C}[22$, с. 7$]$. В отличие от центрально-черноземной полосы Европейской России, характеризующейся по данным видного русского климатолога А.Н. Барановского равенством или подобием средних температур лета и растительного периода на всей своей протяженности, средние температуры полевого сезона в Алтайском округе не были одинаковы [10, с. 30, 37]. Вследствие этого для исследователей была очевидна необходимость вариативного подхода к осуществлению сельскохозяйственного цикла в округе. Например, посевные работы в долинах горной части Алтая можно было начинать в конце мая начале июня, в холмистой - уже в начале мая [14, с. 12], а в степях равнинной части - в конце апреля [23, с. 8].

Уникальность термического режима Алтая обосновывалась учеными ярко выраженной температурной амплитудой (разницей между средними температурами самого жаркого и самого холодного месяцев) $[17$, с. 5-6; 19, с. 5; 23, с. 4; 24, с. 27]. Разница между летними и зимними изотермами для Барнаула фиксировалась в $38,5^{\circ} \mathrm{C}$; Томска - 38,3 ${ }^{\circ} \mathrm{C}$; Москвы $29,9{ }^{\circ} \mathrm{C}$; Нижнего Новгорода $-31,4^{\circ} \mathrm{C}$; Твери $-30,4^{\circ} \mathrm{C}$ $[17$, с. $6 ; 21$, с. 4]. По районам Алтайского округа температурная амплитуда выражалась в следующих цифрах: в равнинном $-35,3^{\circ} \mathrm{C}$, холмистом $-34,3^{\circ} \mathrm{C}$, горном $-36,1^{\circ} \mathrm{C}[10$, с. 40$]$. Подобные изотермические «скачки» предопределили заключение о резко континентальном (материковом) характере климата Алтайского округа в целом. Значительная величина 
годовой амплитуды на Алтае приближала его климат к крайне континентальному, для которого годовая амплитуда равнялась $40{ }^{\circ} \mathrm{C}[19$, с. $5 ; 21$, с. $30 ; 25$, с. 491].

Тем не менее ученые заключали, что сходство Алтайского округа и европейской части России состояло в тождестве температур вегетационного периода $\left(+15^{\circ} \mathrm{C}\right)[10$, с. $30 ; 24$, с. $27 ; 26$, с. 32$]$. Это подтверждалось распространением идентичных черноземной полосе России видов травяной растительности и хлебов [26, с. 32], позволяло крестьянам, проживавшим в Бийском и Барнаульском уездах, выращивать дыни и арбузы [21, с. 30; 27, с. 73; 28, c. 3], переселенцам Бийского уезда предпринимать попытки разведения яблонь [27, с. 74], а арендаторам Бель-Агачской степи - садить табак [23, с. 19]. Однако, как писали авторы издания «Алтай, будущая Калифорния России и царствовавшие на Алтае порядки», весна и осень «не выдерживают здесь своего времени», и потому продолжительность вегетационного периода предельно коротка [20, с. 24]. Практически повсеместно в округе полевые работы отличала чрезвычайная скученность, а продолжительность сельскохозяйственного цикла приближалась к пяти месяцам безостановочного труда $[15$, с. $174 ; 24$, с. $27 ; 26$, с. 32$]$. Факторами, лимитирующими производительность земледелия в округе, назывались нестабильные погодные условия в период вегетации растений, проявлявшиеся в колебаниях внутримесячных (весеннее возвращение холодов и ранние осенние заморозки) и даже суточных температур [29, с. 23].

Ученые акцентировали внимание также на таком маркирующем признаке алтайского климата, как количество выпадающих осадков и варьирование их по временам года. Согласно классификации, предложенной профессором В.Д. Дудецким [30, с. 85], вся территория Алтайского округа была отнесена к группе районов с недостаточным увлажнением, с количеством осадков 350 мм в год [13, с. 21; 22 , с. $32 ; 31$, с. 20]. Описание Алтая как гетерогенной территории позволило установить, что наибольшее количество осадков в год выпадало в горном районе - 699,13 мм; в холмистой части округа выпадало 492,9 мм; в равнинной - 357,53 мм [10, с. 48; 22, с. 7]. Их распределение увязывалось исследователями с географическим причинами: по мере увеличения абсолютной высоты и лесопокрытости местности (лес «задерживал» влагу) возрастало количество осадков [10, с. 50]. Так, для богатых на осадки горной и лесной частей округа было характерно заболачивание почвы и глубокий снежный покров, в то время как степи равнинной части Алтая испытывали резкую нехватку влаги в период вегетации и «страдали» от ветров, выдувавших снег в зимнее время года. Также внимание исследователей привлекла диспропорция в количестве выпадавших осадков в годовом цикле. Отмечалась реальность и постоянство угро- зы неурожаев в округе в связи с плохим увлажнением почвы в период формирования растений (весна) и избыточным количеством осадков в период активного роста или уборки хлебов (вторая половина лета, осень) [13, с. 21; 19, с. 6-7; 31, с. 22]. Указывалось на необходимость нивелирования производственных рисков, связанных с дефицитом влаги в равнинной части округа, путем избрания для культивирования сортов пшеницы, лучше «переносивших» засуху, и отказа от озимого сева [13, с. $21 ; 32$, с. 93].

Оценивая природно-географические условия Алтая, исследователи рубежа XIX-XX вв. представили описание гидрографии региона. Отметив богатство округа водными ресурсами, специалисты указали на неравномерность охвата территории речными артериями. Устанавливалось, что горная и холмистая части хорошо обеспечены проточными водами, поскольку расположены в бассейне реки Обь, а также образующих ее рек Бии и Катуни с многочисленными притоками. Равнинная же часть Алтайского округа входила в сферу двух бассейнов: реки Обь и замкнутого Барабинско-Кулундинского - орошена значительно беднее. При этом ее северо-западная и западная части (Кулундинская степь) $[15$, с. $6 ; 19$, с. $14 ; 33$, с. 210 ; 34, c. 12], а также юго-запад (Бель-Агачская степь) [23, с. 2-3; 34, с. 12] оказались практически полностью лишены поверхностно-проточных вод.

В связи с тем, что в Кулунде старожилами были освоены прежде всего территории по берегам речек и несоленых озер [35, с. 3-9], т.е. был занят традиционный ареал расселения крестьян, а в Бель-Агаче распространение получили лишь сезонные «поселения» арендаторов Кабинета, исследовательское внимание оказалось приковано к проблеме жизнедеятельности в алтайских степях. Ученые писали, что реки в Кулундинской степи не полноводны, покрыты камышами и частью заболочены, а озера преимущественно соленые, содержат обилие насекомых, имеют сероводородный запах и потому не могут служить источниками питьевой воды [35, с. 3; 36, с. 101; 37, c. 22]. Пресноводные же озера степи вследствие заболоченности зимой «задыхаются» и также не подходят для бытового использования [10, с. 20; 38, с. 10]. Как весьма «сложные» были охарактеризованы и условия для развития зернового хозяйства в Бель-Агачской степи, «неудобной для постоянной жизни человека в силу полной невозможности добыть питьевую воду из наземных или подземных источников» [23, с. 2-3; 34, с. 12]. Единственным доступным способом получения воды здесь являлось строительство снежников (по-казахски «карлыков») - специальных сооружений для сохранения влаги в твердом виде, в состоянии снега и льда [23, с. 4-5; 34 , с. $13 ; 39$, с. 16, 20]. Успешность земледелия в данной локальной зоне, по мнению исследователей, зависела исключительно от количества выпадавших 
осадков. Подчеркивались крайне нестабильная урожайность и ее компенсаторный характер, т.е. восполнявшийся исключительно валовыми сборами зерновых в благоприятные «мочливые» годы [23, с. 13].

Зачастую в трудах ученых-естественников собственно географические описания тесно переплетались с этнографическими наблюдениями. Ученые связывали сложность решения проблемы маловодья в алтайских степях с традиционными представлениями сибирских крестьян об исключительной важности использования в быту воды из естественных источников. Например, Г.И. Танфильев, исследовавший Барабу и Кулундинскую степь по поручению геологической части Кабинета в 1899-1901 гг., обратил внимание на пренебрежительное отношение сибирского населения к жесткой колодезной воде и предпочтительное потребление для хозяйственных нужд речной, прудовой или озерной воды. Откровенное удивление специалиста вызвал характер эксплуатации крестьянами ограниченных водных ресурсов, которые загрязнялись навозом и бытовыми отходами. Более того, в труде географа содержалось суждение, что кулундинские крестьяне расценивали воду, загрязненную навозом и мхом, как особенно полезную и использовали в пищу без предварительного кипячения. Г.И. Танфильев вспоминал, что ему предлагали для питья зловонную воду чайного цвета, вкус которой не исправляло даже добавление клюквенного экстракта [36, с. 136]. Подмеченное не носило характер исключительности и подтверждалось сведениями других ученых [10, с. 22; 40, с. 114-115; 41, с. 4-5].

Важнейшим элементом географической среды Алтая являлись почвенные условия, которые рассматривались учеными обозначенного периода в соответствии с концепцией профессора В.В. Докучаева как продукт взаимодействия местного климата, растений, животных микроорганизмов, состава и строения материнских горных пород, а также рельефа $[10$, с. I; 18, с. $11 ; 42$, с. $20 ; 43$, с. 2]. При этом выдающийся сибирский ученый-почвовед доктор сельскохозяйственных наук К.П. Горшенин отмечал, что пестрота почвенного покрова ЗападноСибирской низменности препятствует строгой зональности в связи с внедрением большого количества интрозональных почв и региональной спецификой почвы, приобретаемой под влиянием местных условий [44, с. 51-52]. Потому географы констатировали чрезвычайное разнообразие почвенных условий всего Алтая. Так, почвовед И.П. Выдрин выделил 13 типов почв, преобладавших в различных уездах округа [45, с. 6]. Данные сведения имели важное прикладное значение, поскольку ставили на повестку дня вопрос о разной степени плодородия алтайских земель. Признавая разнообразие почвенного режима Алтайского округа, мы с определенной долей условности посчитали возможным подразделить тер- риторию региона на три основные почвенные зоны (район каштановых почв, район черноземных почв, район подзолистых почв) [18, с. 10; 46, с. 32], пределы распространения которых не в полной мере совпадали с делением территории на равнинную, холмистую и горную части.

Другой особенностью почвенного режима Алтая являлось значительное распространение низкопродуктивных солонцов [15, с. 9]. В целом, производительные свойства почв Алтая высоко оценивались современниками $[47$, с. 196,$251 ; 48$, с. $127 ; 49$, с. 43]. В то же время они констатировали, что «сибирские земли не так богаты черноземом, как русские, и таким толстым слоем, как в России, чернозем ... нигде не лежит» [48, с. 125], «к здешней земле надо подходить с сибирской, а не российской меркой...» $[14$, с. 9]. Отмечая высокую степень плодородия алтайской земли по сравнению с землями других районов Зауралья, исследователи зафиксировали такую ее отрицательную характеристику, как быстрое «выпахивание» [11, с. 42; 14, с. 7; 48, с. 127; 50, с. 42; 51, с. 242]. Так, по некоторым свидетельствам, лучшие черноземы Алтайского округа теряли производительный потенциал уже через 10-15 лет обработки [48, с. 127; 51, с. 242]. А по сведениям Г.Е. Катанаева, в Бель-Агачской степи распашка и посев пшеницы в одном и том же месте производилась на совсем «мизерный срок» - не более трех лет [23, с. 12]. Восстановлению производительности почвы могло бы способствовать, по мнению специалистов, применение удобрений, что по целому ряду причин не практиковалось алтайскими земледельцами [52, с. 61]. В частности, крестьяне не умели точно определять время вывоза навоза на поля, рассчитывать требуемое количество удобрений для различных по качеству пашен [53, с. 287]. А почвоведы И.П. Выдрин и 3.И. Ростовский предполагали, что во многом интуитивная крестьянская формула «земля навозу не принимает» имеет под собой рациональные основания. Согласно гипотезе ученых, использование удобрений привело бы к более роскошному цветению и повышению кустистости растений, что задержало бы созревание, а при краткости вегетационного периода в Сибири обернулось бы их гибелью от рано наступающих холодов [42, с. 4].

Еще одной отличительной чертой алтайских почв выступала их «склонность» к быстрому зарастанию сорными травами, что одновременно являлось маркером истощения почв и сигнализировало о необходимости отдыха для пашни [32, с. $31 ; 52$, с. 61 ; 54 , с. $153 ; 55$, с. 5]. Причины этих явлений крылись в «тароватости» (кратковременная производительность) [42, с. 2; 56, с. 303-304, 318; 57, с. 53] почвы, дававшей хорошие урожаи прежде всего на «молодых» и свежих пашнях. В сравнении с «вековечными» черноземами Европейской России, обеспечивавшими урожайность на длительное время, земли Алтая в целом отличала меньшая мощность и потому более 
быстрое истощение [10, с. V; 42, с. 52-53]. Даже богатые содержанием перегноя лесные земли Алтайского округа, выделявшиеся высокой и устойчивой урожайностью на фоне хорошей обеспеченности осадками горной части региона, не могли обеспечить стабильного сбора зерновых ввиду особенностей термического режима местности (весенние возвраты холодов, ранние осенние заморозки и т.д.) [10, с. VI].

Исследователи, фиксируя «тяжесть» в обработке сибирских почв, подчеркивали «негодность» российской сохи для твердой и плотной алтайской земли, насущную необходимость применения «тяжелых» пропашных орудий: сохи «колесянки» и «рогамола» или плуга [53, с. $288 ; 54$, с. $134-135 ; 55$, с. 5]. Эти виды сельскохозяйственных орудий, по мнению специалистов, обеспечивали глубокую вспашку, сохранявшую продуктивную влагу в почве, а также глубокую «заделку» семян, что в некоторой мере нивелировало отрицательные стороны условий земледельческого производства в округе.

Таким образом, в конце XIX - начале XX в. естественно-географические условия Алтайского округа составили объект исследования для ученых и путешественников, а также представителей различных структур и ведомств. Во многом побудительной силой к публикационной активности явились значительные трансформации региона в хозяйственно-экономической, демографической и социокультурной сферах, порожденные массовыми крестьянскими переселениями. Потому перед значительной частью авторов, прежде всего перед сотрудниками переселенческих организаций и региональных структур, стояли задачи колонизационной экспертизы территории, поиска подходящих для земледельцев лакун для нивелирования трудностей, связанных с обустройством на новом месте. Достижением данного периода явились заключения о гетерогенности природно-климатических условий Алтая, отход от во многом обывательского и поверхностного заключения о его земледельческом богатстве, осуществление природно-географического районирования территории при создании конкретного описания различных естественных параметров. Именно в это время были заложены основы для естественно-научного изучения региона, происходит «осознание» его уникальности и особости сравнительно с сельскохозяйственными районами Европейской России.

\section{Библиографический список}

1. Чуркин М.К. Природный фактор в аграрной колонизации Сибири пореформенного периода: становление историко-географического дискурса // Вестник Омского университета. Серия: Исторические науки. 2014. № 4 (4).

2. Чуркин М.К. Переселение крестьян черноземного центра Европейской России в Западную Сибирь во второй половине XIX - начале XX вв.: детерминирующие факторы миграционной мобильности и адаптации : монография. Омск, 2006.

3. Дорофеев М.В. Крестьянское землепользование в Западной Сибири во второй половине XIX века. Томск, 2009.

4. Чуркин М.К. Природно-географический фактор и адаптация переселенцев Европейской России в Западной Сибири (вторая половина XIX - начало XX вв.) // В мире научных открытий. 2013. № 11-3 (47).

5. Силантьева М.М. История исследования растительного покрова Алтайского края. Барнаул, 2013.

6. Пожарская К.А. Народные источники формирования образа Сибири в представлениях потенциальных переселенцев конца XIX - начала XX столетия // Экономическая история Сибири XX - начала XXI в.: сборник статей по материалам IV Всероссийской научной конференции, Барнаул, 26-27 июня 2015 г. Барнаул, 2015.

7. Голубев П.А. Алтай. Историко-статистический сборник по вопросам экономического и гражданского развития Алтайского горного округа. Томск, 1890.
8. Сельскохозяйственный обзор Алтайского округа за 1896 г. Барнаул, 1897.

9. Сибирь. Общие замечания о Сибири и переселении. Сведения о земледельческой полосе Сибири. Вып. 1. СПб., 1897.

10. Выдрин И.П., Ростовский 3.И. Материалы по исследованию почв Алтайского округа. Барнаул, 1899.

11. Сведения о земледельческой полосе Сибири. Вып. VII. СПб., 1901.

12. Яблонский Н.В. Путеводитель по Алтаю. Томск, 1902.

13. Морозов И.М. Алтайский округ в колонизационном отношении. Полтава, 1908.

14. Мамырин Г. Краткие сведения о Томской губернии. Полтава, 1912.

15. Никольский В.В. Материалы по экономическому исследованию внутренних водных путей. Отдел II: Сельское хозяйство в Алтайском округе. СПб., 1916.

16. Статистико-экономические бюллетени. 1917. № 6.

17. Бажаев В.Г. Очерк климатических условий Томской губернии. Томск, 1896.

18. Алтайский ежегодник за 1921-1922 хозяйственный год. Барнаул, 1923.

19. Березовский Е.П. Климат и гидрография Алтайского края // Алтайский сборник. Барнаул, 1930. Т. 12.

20. Алтай, будущая Калифорния России и царствовавшие на Алтае порядки. Продолжение к книге «Северные сеяния» / ред.-изд. В. Отпетый. Лейпциг, 1882. 
21. Орлов А.А. Климат Алтая. СПб., 1912.

22. Морозов И.М. Алтайский округ в сельскохозяйственном отношении и условия жизни переселенцев в нем. Харьков, 1908.

23. Катанаев Г.Е. Хлебопашество в Бельагачской безводной степи Алтайского горного округа // Записки Западно-Сибирского отдела Императорского русского географического общества. Кн. XV, вып. II. Омск, 1893.

24. Сибирь и великая сибирская железная дорога. Б.м., 1896

25. Воейков А.И. Климаты земного шара в особенности России. СПб., 1884.

26. Петров М. Западная Сибирь: губернии Тобольская и Томская. М., 1908.

27. Головачев П. М. Сибирь. М., Б. г.

28. Косменко-Загорский В.П. О переселении в Кулундинскую степь Барнаульского уезда Томской губернии. Чернигов, 1909.

29. Миддендорф А.Ф. Бараба. СПб., 1871.

30. Дудецкий В.Д. Опыт климатического районирования черноземной полосы Западной Сибири // Известия Западно-Сибирского отдела Русского географического общества. Т. 5. Омск, 1926.

31. Бажаев В.Г. О системах земледелия в Томской губернии. Томск, 1896.

32. Швецов С.П. Материалы по исследованию мест водворения переселенцев в Алтайском округе. Результаты статистического исследования в 1894 г. Вып. II. Барнаул, 1899.

33. Семенов-Тян-Шанский П.П. Географическо-статистический словарь Российской империи. СПб., 1863. Т. I.

34. Струков М.И. Краткий очерк Алтайского округа ведомства Кабинета Его Императорского Величества. СПб., 1896.

35. М.К. Ведение крестьянами Кулундинского района своего хозяйства и меры его улучшения // Алтайский крестьянин. 1914. №5. 1 февр.

36. Танфильев Г.И. Бараба и Кулундинская степь в пределах Алтайского округа. СПб., 1902.

37. Переселение в губернии Тобольскую, Томскую, Енисейскую и Иркутскую в 1907 г. Справочная книжка о переселении в лесную и лесостепную полосы Сибири. Вып. ХХХІХ. СПб., 1907.

38. Вашкевич Т.Г. Кулундинская равнина как колонизационный фонд // Известия областной земской переселенческой организации. Полтава, 1909. № 14-15. 15 апр.

39. Шкунов М.В. Итоги статистического обследования Бельагачской степи Змеиногорского уезда Томской губернии, произведенного в 1908 г. чинами Алтайского переселенческого отряда. Барнаул, 1909.
40. Залесский С.И. Исследование пригодности некоторых маловодных местностей Барнаульского и Каинского округа к заселению переселенцами из Европейской России. Отчет о командировке, состоявшейся летом 1893 г., по предложению Господина Томского губернатора. Томск, 1893.

41. Нагнибеда В.Я. Томская губерния. Статистический очерк. Томск, 1917.

42. Выдрин И.П., Ростовский З.И. Предварительный отчет по исследованию почв северной части Алтайского округа. Барнаул, 1896.

43. Труды почвенно-ботанической экспедиции колонизационных районов Азиатской России. Ч. 1: Почвенные исследования 1909 г. Вып. 1: О почвах западной части Горного Алтая между бассейнами рек Катуни и Чарыша / ред. К. Д. Глинка. СПб., 1910.

44. Горшенин К.П. Почвы черноземной полосы Западной Сибири // Записки Западно-Сибирского отдела Государственного Русского географического общества. Т. 39. Омск, 1927.

45. Бюллетени Алтайского губернского статистического бюро. 1920.№ 2. 12 ноября.

46. Очерки Алтайского края / редкол. Б. М. Быкова [и др.]. Барнаул, 1925.

47. Завалишин И. Описание Западной Сибири. Томская губерния. М., 1865. T. II.

48. Рубакин Н. Рассказы о Западной Сибири или о губерниях Тобольской и Томской и как там живут люди. М., 1908.

49. Арефьев В. Описание Сибири. Очерки для народного чтения. Вып. I: Географическое положение и природа Сибири. Томск, 1900.

50. Переселение из Полтавской губернии с 1861 г. по 1 июня 1900 г. Вып. І. Пг., 1900.

51. Кирьяков В.В. Очерки по истории переселенческого движения в Сибирь (в связи с историей заселения Сибири). М., 1902.

52. Деятельность черниговского губернского земства по переселению в осенний сезон 1908 г. Чернигов, 1909.

53. Россия. Полное географическое описание нашего отечества. Настольная и дорожная книга для русских людей / под ред. В.П. Семенова-Тянь-Шанского. СПб., 1907.

54. Крестьянское землепользование и хозяйство в Тобольской и Томской губерниях. По исследованиям чинов министерства государственных имуществ. СПб., 1894.

55. Сибирское переселение. СПб., 1896.

56. Докучаев В.В. По вопросу о сибирском черноземе // Труды императорского вольного экономического общества. СПб., 1882. Т. 2, вып. 3.

57. Варгин В.Н. Почвоведение. Пг., 1915. 